\title{
Physical properties of a fine textured haplocambid after three years of organic matter amendments management
}

\author{
O. Seguel ${ }^{1 *}$, C. Baginsky ${ }^{1}$, A. Contreras ${ }^{1}$, J. I. Covarrubias ${ }^{1}$, C. González ${ }^{1}$, L. Poblete ${ }^{1}$ \\ ${ }^{1}$ Universidad de Chile, Facultad de Ciencias Agronómicas, Departamento de Ingeniería y Suelos. Santiago,Chile. "Corresponding \\ author.oseguel@uchile.cl
}

\begin{abstract}
In Copiapó Valley, the $3^{\text {th }}$ Region of Chile, a three-year study (2007-2009) was conducted to evaluate the effect of organic amendments and cover crops on soil physical properties (Typic Haplocambid) in a table grape (Vitis vinifera) orchard. Four treatments were established during three seasons: control without organic amendments (T1), broad bean-corn-rape rotation (T2), goat manure addition (15 t ha-1) (T3) and corn-broad bean-barley rotation (T4). Soils measurements, bulk density, pore size distribution, aggregate stability, water repellence and air conductivity were conducted on soil samples collected at three soil depths $(0-10,10-30$ and $30-50 \mathrm{~cm})$. Saturated hydraulic conductivity and mechanical strength were also evaluated. On grape plant measurements, root development, pruning weight and harvested grape production were evaluated. Soil bulk density was reduced with goat manure addition in comparison with any other treatment, which resulted in lower mechanical strength in the top soils. None of the treatments had negative effects on water repellency. The crop treatments enhanced the coarse porosity throughout the soil profile, improving the continuity of porous system with their root development and inducing high air conductivity. Other hand, the control soil and manure application showed a pore discontinuity in a pre-existing plow pan. Aggregate stability and saturated hydraulic conductivity were greater in goat manure application, but the treatments which included crop rotation did not show significant differences compared with the control. Because of the short duration of the study, it is assumed that the soil improvements were not detected as expected in grape production yet.
\end{abstract}

Keywords: Compaction, cover crops, aggregate stability, soil porosity 


\section{Introduction}

In agricultural production systems, one of the most common physical-mechanical alterations is soil compaction (Ellies, 1995), which affects the storage and transport of water and air (Dörner and Horn, 2006). Compaction is the loss of volume for a given soil mass due to external forces (Warrick, 2002). In agricultural soils, its magnitude depends on anthropic factors such as machinery transit and on the pedological characteristics of the soil (Horn and Lebert, 1994). Compaction produces productivity limitations by affecting soil physical properties such as dynamics of water and air in the soil profile, which in turn impact the biological activity (Montico and Bonel, 2005).

Loss of soil volume during compaction is due to the loss of coarse pores (mainly macropores $>10 \mathrm{um}$ ), producing anaerobic conditions. Fine-textured soils are highly compressible and they are prone to be compacted, particularly if they are not well structured (Horn and Lebert, 1994). The main factor that facilitates soil degradation by compaction is soil organic matter (SOM) losses. Soil structure maintenances are achieved by greater stability of the soil aggregates, which in turn strongly correlate with SOM content and rooting activity (Oades, 1993; Ellies, 1995). Primary organo-mineral complexes are defined as organic matter bound to mineral particles, which offer organic chemical carbon protection against biodegradation and prevent the loss of free organic matter (Chenu and Plante, 2006). Also, organic-mineral unions increase the points of contact with other particles, facilitating the physical protection of SOM in soil aggregates (Zhang et al., 1997). Finally, root exudation promotes the release of carbonaceous compounds facilitating soil aggregation (Oades, 1993).

Soil structure modifications are crucial for those impacting on the distribution of pore sizes (Ellies, 1995). The measurements of this property may help to quantify the impact of management practices on soil functionality. The quantification of pore spaces in terms of quantity, size and continuity of pores in the soil provides a measure of the complexity of soil structure and an understanding of the modifications produced by land-use, which can lead to improved land-use management practices that enhance the protection of the environment (Pagliai and Vignozzi, 2002).

The use of cover crops rotations should be considered as an alternative of organic matter amendment because they may impact positively soil conditions for crops growth (Trükmann et al., 2006). The application of organic amendments to soils seeks to increase water retention and macropores $(>10-30 \mu \mathrm{m})$ mainly through biological activity (Warrick, 2002; Seguel et al., 2003). Organic amendments to fine-textured soils also can improve the elastic behaviour of the soil, enhancing soil structure and preventing soil compaction (Zhang et al., 1997). As the roots of cover crops form new pores network, they also expand in diameter and length, producing an agglutination the soil particles (Kay, 1990) resulting in a pore with much greater stability when roots die (Oades, 1993).

In northern Chile (Atacama region in Chile), there are favourable climatic conditions for the production of table grapes; nevertheless, soils lack of adequate organic matter contents (CIREN, 2007). Organic amendments often include using goat manure, with large quantities of fresh organic matter being applied on the row plantation. Manure application induces rapid changes in the physical soil properties including mechanical resistance and water movement in the soil. However, they also promote discontinuities in the pore system and a chemical constrains such as increasing salts concentrations (Baginsky et al., 2010).

In the Atacama region is necessary the identification of alternative sources of soil organic amendments that would avoid the undesirable changes of soil properties that are associated with manuring. A previous study in the region evaluated the effect of different crop rotations on physical properties of soil, but the use of manure was not included (Seguel et al., 2011). 
In this work we evaluated the use of cover crop in contrast to the effect of manure application.

The aim of this study was to evaluate the effect of organic matter amendment during three years on soil properties in a fine textured soil in northern Chile. We evaluated the effect of cover crops and manure applications on soil physical properties and vine production to test remedial management protocols to improve soil properties related with plant productivity.

\section{Materials and Methods}

\subsection{Study site}

The study was conducted from 2007 to 2010 on a farm $16 \mathrm{~km}$ east of the city of Copiapó, in an orchard of Vitis vinifera $\left(27^{\circ} 32^{\prime} 50^{\prime \prime} \mathrm{S} ; 7^{\circ} 15^{\prime} 50^{\prime \prime} \mathrm{W}\right)$. Soil evaluations were done at the Faculty of Agricultural Sciences, University of Chile the last year of the trial (2009). The study site is located in a Transitional Desert Climate (Juliá et al., 2008), which is characterized by low winter precipitation of around $20 \mathrm{~mm}$ per year, with daily average temperatures fluctuating between $25^{\circ} \mathrm{C}$ in summer and $5^{\circ} \mathrm{C}$ in winter.

The soil belongs to La Capilla soil series, corresponding to Fine loamy, mixed, calcareous, thermic, Typic Haplocambid Family, according to CIREN (2007). It is located in an alluvial remnant terrace with a slight slope $(1 \%)$ and is well drained. Following Poblete (2011), textures are clay loam to sandy clay loam (22 to $33 \%$ of clay content and 36 to $54 \%$ of sand content), but below $120 \mathrm{~cm}$ there is a sandy substrate (CIREN, 2007). The Ap horizon is strongly saline and there is a violent effervescence with $\mathrm{HCl}$ throughout the profile.

\subsection{Treatments and experimental design}

The experiment was established in an eight years old table grape orchard (Vitis vinifera) cv. Flame Seedless, trained to an overhead trellised system in a $3.5 \times 3.5$ $\mathrm{m}^{2}$ distribution. Twenty plots with four treatments were located within five complete randomized blocks (Table 1), where a combination of different crops rotation or goat manure addition were imposed on the row planting of vines, without interfering with the inter-row. Crops used in the rotations were: broad bean (Vicia faba) Aguadulce variety; corn (Zea mays) San Pablo hybrid; rape (Brassica napus var. napus) L-456 variety and barley (Hordeum vulgare) Aurora variety. These annual crops were sown by hand on the ridge $(1 \mathrm{~m}$ wide) during February of each year. For broad beans, a commercial inoculant of Rhizobium leguminosarum bv. viciae was applied (150 g of inoculant per $50 \mathrm{~kg}$ seed) before sowing. Broad bean and corn were established in five rows spaced at 15 and $25 \mathrm{~cm}$ respectively, with a planting distance on the row of $15 \mathrm{~cm}$ and at a depth of 10 and $5 \mathrm{~cm}$, respectively, with an approximate dose of $80 \mathrm{~kg} \mathrm{ha}^{-1}$ for broad been and $55 \mathrm{~kg} \mathrm{ha}^{-1}$ for corn. Rape and barley were sown in a continuous stream (3 $\mathrm{cm}$ depth) in seven rows separated by $15 \mathrm{~cm}$, in doses of 15 and $70 \mathrm{~kg} \mathrm{ha}^{-1}$, respectively.

Table 1. Treatments and crop rotations on vine rows during the 2007-2009 seasons.

\begin{tabular}{cccc}
\hline Treatment & \multicolumn{3}{c}{ Year } \\
\cline { 2 - 4 } & 2007 & 2008 & 2009 \\
\hline T1 & Control & Control & Control \\
T2 & Broad bean & Corn & Rape \\
T3 & Manure $^{1}$ & Manure & Manure \\
T4 & Corn & Broad bean & Barley \\
\hline
\end{tabular}

Goat manure $15 \mathrm{tha}^{-1}$

The soil was characterized morphologically in three pits arranged randomly to verify the homogeneity of the site. The experimental unit was a $15 \mathrm{~m}$ long by 1 $\mathrm{m}$ wide plot containing 4 vines with their respective median (10 cm height ridge). To avoid a border effect, only the two central plants and the corresponding soils were included for soil/plant evaluations. 
The orchard used a drip irrigation system with double line and drippers of $4 \mathrm{~L} \mathrm{~h}^{-1}$ separated at $1 \mathrm{~m}$ on the line. Irrigation was controlled by a climatic station located close to the study site. Irrigation criteria considered crop evapotranspiration, applying irrigation every four days and totaling $12,000 \mathrm{~m}^{3}$ of water for irrigation during the season. Rainfall was negligible during the study period, with less than $10 \mathrm{~mm}$ per year falling during June-July. Previous to sowing the crop treatments, an extra irrigation was applied, but during the season fertilization and irrigation were based on the needs of vines, following the normal program used by the farmer. Fertilization included $120 \mathrm{~kg} \mathrm{~N} \mathrm{ha}^{-1}, 30$ $\mathrm{kg} \mathrm{P}_{2} \mathrm{O}_{5}$ ha $^{-1}, 120 \mathrm{~kg} \mathrm{~K}_{2} \mathrm{O} \mathrm{ha}^{-1}, 100 \mathrm{~kg} \mathrm{CaO} \mathrm{ha}^{-1}, 30 \mathrm{~kg}$ $\mathrm{MgO} \mathrm{ha}^{-1}$ and an especial mixture of micro nutrients, all of them fractioned in four equal applications from sprouting to postharvest. Weeds were manually controlled. Crops treatments were early harvested before the application of a sprouting controller (hydrogen cyanamide) in July, then they were chopped and distributed on the inter-row median to: (1) decrease the effect of truck wheels of agricultural machinery in the inter-row median and (2) extract the salts from the ridge through the dry matter of crops.

Goat manure was applied at an input rate of $0.08 \mathrm{~m}^{3}$ $\left(40 \mathrm{~kg} \mathrm{plant}^{-1}\right)$ in May of each year. The manure was distributed into a soil pits on the row planting, with dimensions of $2 \mathrm{~m}$ long, $0.5 \mathrm{~m}$ wide and $0.3 \mathrm{~m}$ depth. The manure was covered by pruning material to promote adequate conditions for microbial activity during the experiment. Each year the manure application was made on the top soil without altering the soil surface.

\subsection{Soil sampling and evaluations}

On August 2009 and 24 hours after irrigation, 20 soil pits were excavated $(70 \mathrm{~cm}$ depth, one per experimental unit) on the row at the center of two plants. Samples were taken at $0-10 ; 10-30$ and $30-50 \mathrm{~cm}$ in order to measure soil physical properties.

Particle density (Dp) was measured in sieved samples at $2 \mathrm{~mm}$ by using picnometer (Flint and Flint, 2002).
Soil texture was determined by the Bouyoucos method (Gee and Or, 2002) using composed samples from each treatment and depth.

The water retention curve (Dane and Hopmans, 2002) was determined by measuring the volumetric water content of soil at different tensions using cylinders of 5 $\mathrm{cm}$ height and $6 \mathrm{~cm}$ in diameter to obtain non-disturbed samples (one replicate per depth, 60 samples in total). The cores were subjected to tensions of $0.2 ; 3 ; 6 ; 30$ and $100 \mathrm{kPa}$ in sand box and pressure plate extractor until to reach the equilibrium (variable between 2 and 6 days). With samples equilibrated at $-30 \mathrm{kPa}$ the airflow was measured using a convection device. Details of the method are found and explained by Farías (2009). When the water extraction process ended $(-100 \mathrm{kPa})$ the bulk density $(\mathrm{Db})$ was measured from the same cylinders (Grossman and Reinsch, 2002). With the values of Dp and $\mathrm{Db}$, the total porosity (TP, \%) was calculated by TP $=[1-(\mathrm{Db} / \mathrm{Dp})] \cdot 100$. To determine the wilting point $(1500 \mathrm{kPa})$, we used disturbed soil samples in a pressure plate extractor (Dane and Hopmans, 2002), converting the weight-base water content $(\mathrm{Pw})$ to volumetric water content $(\mathrm{Pv})$ by $\mathrm{Pv}=\mathrm{Pw} \cdot \mathrm{Db}$. Based on Hartge and Horn (2009), with the data from water retention curve the fast drainage pores (FDP, $>50 \mu \mathrm{m}$ ) was calculated as the difference between the total porosity and the equilibrium at $-6 \mathrm{kPa}$; the slow drainage pores (SDP, 10$50 \mu \mathrm{m})$ was calculated as the difference between water content at -6 and $-33 \mathrm{kPa}$, and the water availability (WA, $0.2-10 \mu \mathrm{m}$ ) was calculated as the difference between water retention at -33 and $-1500 \mathrm{kPa}$.

The infiltration rate (Reynold et al., 2002) was determined in the field by the cylinder method (30 $\mathrm{cm}$ in diameter and $40 \mathrm{~cm}$ in height), measuring the height of water infiltrated into the soil (one replicate per experimental unit between the two central plants) at different times $(0,5,10,20,30,45,60,90,120$ and 180 minutes). With the slope of the stabilized curve of accumulated infiltration, the rate (slope) was calculated, assuming that it is equivalent to the stabilized velocity of infiltration. 
To determine a possible hydrophobic effect of $\mathrm{OM}$ on soil behavior, the sorptivity in water and ethanol were measured according to the methodology of LeedsHarrison et al. (1994), determining the repellence index (R) in non-disturbed simples equilibrated at water tension of $-33 \mathrm{kPa}$.

To evaluate the resistance to penetration a digital effort meter (EXTECH, model $475044,30^{\circ}$ cone and $0.7 \mathrm{~cm}$ in diameter) was used in the soil pits (Terzaghi and Peck, 1983). Vertical and horizontal measurements were taken with three replicates at three depths (5, 20 and $45 \mathrm{~cm}$ ), totaling 9 measurements per soil pit from a total of 20 pits. The evaluations were carried out below the drip zone, 24 hours after irrigation, determining the rest coefficient (ko) which, according to Terzaghi and Peck (1983) corresponds to ko $=o_{x, y}$ $/ o_{z}^{*}$, where $o_{x, y}$ is the horizontal strength and $o_{z}^{\prime}$ is the vertical strength.

The macro-aggregate stability to water was measured as the variation in diameter of dry and wet sieving (Hartge and Horn, 2009). To assess this, 200 grams of a random sample (air-dry aggregates $2-30 \mathrm{~mm}$ ) was sieved in a group of sieves (ordered from the largest on the top to the finest at the bottom) of $19 ; 9.5 ; 6.68 ; 4.75$; 3.32 and $2 \mathrm{~mm}$ at 60 Hertz for one minute, producing a rupture on natural failure planes as a consequence of mechanical friction. The aggregates retained in each sieve and the remainder material $(<2 \mathrm{~mm})$ were weighed and expressed as the cumulative fraction (from finest to largest) respect to the total initial dry weight (dry sieving). The process was repeated, sieving the sample submerged in water at $60 \mathrm{rpm}$ for 5 minutes in a $5 \mathrm{~cm}$ movement up and down. This treatment produces a new rupture of aggregates as a consequence of abrasive action of water. The material of each sieve is recovered, dried at $105^{\circ} \mathrm{C}$ during 24 hours and weighed, expressing the cumulative fraction respect to the total initial dry weight (wet sieving). The stability was determined by measuring the relative change in diameter of the aggregates at $80 \%$ (VD80) of the cumulative fraction based on mass for each sieving (dry and wet).
To determine possible salt accumulation on the surface, composite samples per treatment at $0-5$ and 20-30 cm depth were collected (August 2009), and measured for Electrical Conductivity (EC), soluble boron, available chlorine and exchangeable sodium. In January 2010 we performed a final sampling (0$20 \mathrm{~cm}$ depth) to determine $\mathrm{pH}$, total organic matter, total nitrogen, available phosphorus and exchangeable potassium with five replicates. Samples were sieved $2 \mathrm{~mm}$ and coarse materials were hand picked and the samples were stored for the analysis. In parallel, a portion of soil was oven dry for $48 \mathrm{~h}$ at $105^{\circ} \mathrm{C}$ for soil moisture content. All the methodologies are detailed in Sadzawka et al. (2004).

To evaluate the effect of treatments on vine production at the end of the study, the dry matter of roots ( $g$ $\mathrm{L}^{-1}$ of soil), the commercial grape production $(\mathrm{kg}$ plant $\left.{ }^{-1}\right)$ and the fresh pruning mass $\left(\mathrm{kg} \mathrm{plant}^{-1}\right)$ were measured in August 2009, January 2010 and May 2010 , respectively. The roots were collected using a hand-made riverside auger $(6.6 \mathrm{~cm}$ in diameter and $17 \mathrm{~cm}$ height), taking soil samples at depths of $0-20$ and $20-40 \mathrm{~cm}$, at a distance of $50 \mathrm{~cm}$ from the central plants of each experimental unit. In the lab, samples were gently disaggregated and dried $\left(20^{\circ} \mathrm{C}\right)$ for two weeks, separating the roots from the soil. The roots were classified into fine $(<2 \mathrm{~mm})$ and coarse $(>2 \mathrm{~mm})$ roots and dried at $65^{\circ} \mathrm{C}$ until constant weight. All these evaluations considered the average of the two central plants from each experimental unit.

\subsection{Statistical analysis}

An analysis of variance (ANOVA) was performed with a confidence level of $95 \%$ and with prior verification of assumptions about the error terms. We used the Anderson-Darling test to verify the assumption of normality, and Bartlett's test for homogeneity of variances. When significant differences were detected, we performed a multiple range test (LSD, $p<0.05$ ). In addition, correlations between soil variables were performed and the slopes of the stabilized infiltration were compared by a t-test. 


\section{Results and Discussion}

\subsection{General soil physical and chemical properties}

Soils showed high texture homogeneity, both at the surface and at greater depths. The sand, silt and clay content varied, respectively, between $41-47 \%, 23$ $29 \%$ and $22-31 \%$ in the surface horizon $(0-10 \mathrm{~cm})$ and $36-46 \%, 24-34 \%$ and $29-34 \%$ at different depths $(10-60 \mathrm{~cm})$. The textural classes varied from clay loam to sandy clay loam. Particle density (Dp) ranged between 2.58 and $2.71 \mathrm{Mg} \mathrm{m}^{-3}$ within the range expected for mineral soils (Warrick, 2002). The only exception was treatment T3 (manure), where the Dp at $0-10 \mathrm{~cm}$ was $2.50 \mathrm{Mg} \mathrm{m}^{-3}$ as a result of the application of goat manure. Organic materials generally give $\mathrm{Dp}$ values between 1.2 and $2.0 \mathrm{Mg} \mathrm{m}^{-3}$ (Warrick, 2002), thus the application of manure in T3 produced an expected decrease in Dp (Seguel et al., 2003). Densification of the soil, evaluated as bulk density (Db), after three years of managements are summarized in Table 2.

Table 2. Bulk density ( $\left.\mathrm{Mg} \mathrm{m}^{-3}\right)$ of treatments as a function of soil depths. Means ( \pm standard error of the mean). Bulk densities were determined at the end of the field experiments in August 2009.

\begin{tabular}{clcc}
\hline Treataments & \multicolumn{3}{c}{ Bulk density $\mathbf{( M g ~ \mathbf { ~ m } ^ { - 3 } )}$} \\
\cline { 2 - 4 } & \multicolumn{1}{c}{$\mathbf{0 - 1 0} \mathbf{~ c m}$} & $\mathbf{1 0 - 3 0 ~ c m}$ & $\mathbf{3 0 - 5 0 ~ c m ~}$ \\
\hline T1 & $1.46( \pm 0.03) \mathrm{a}$ & $1.62( \pm 0.04) \mathrm{a}$ & $1.66( \pm 0.06) \mathrm{a}$ \\
T2 & $1.44( \pm 0.01) \mathrm{a}$ & $1.50( \pm 0.04) \mathrm{ab}$ & $1.62( \pm 0.03) \mathrm{a}$ \\
T3 & $1.02( \pm 0.10) \mathrm{b}$ & $1.47( \pm 0.07) \mathrm{b}$ & $1.61( \pm 0.04) \mathrm{a}$ \\
T4 & $1.37( \pm 0.07) \mathrm{a}$ & $1.57( \pm 0.02) \mathrm{ab}$ & $1.65( \pm 0.04) \mathrm{a}$ \\
\hline
\end{tabular}

Different letters in the same column indicate significant differences between treatments at the same depth $(p<0.05)$. An explanation of the treatments is given in Table 1 .

Bulk density $(\mathrm{Db})$ is one of the properties that is most sensitive to anthropic soil interventions (Zeng et al., 2013). In the manure application treatment (T3) $\mathrm{Db}$ was significantly lower up to $30 \mathrm{~cm}$ in depth and which coincided with the depth of the soil intervention; however, this effect was diluted across the profile since the amendment was incorporated into the topsoil. Although the treatments with crops (T2 and T4) did not show significant differences from the control, their bulk-density values were lower compared with $\mathrm{T} 1$, especially from $10-30 \mathrm{~cm}$. This high porosity was generated by the development of roots, which are able to displace particles, generating coarse porosity as they grow in length and diameter (Kay, 1990).

\subsection{Pore size distribution}

Treatment T3 (manure), as expected, had the highest water retention at low tensions (data not shown), demonstrating the capacity of organic material to store water. Treatment T4 (corn - broad bean - barley rotation) also showed good water retention from $0-10$ 
$\mathrm{cm}$, as the crop rotation regime left more dense roots in the first layer. Our results support the findings of Kay (1990) that the root grasses are efficient in generating and incorporating organic material in the soil. The pore size distribution by treatment is given in Table 3.

Table 3. Distribution of pore sizes (\%) for the treatments as a function of soil depth. Means ( \pm standard error of the mean).

\begin{tabular}{|c|c|c|c|c|}
\hline \multirow{2}{*}{$\begin{array}{c}\text { Pore size } \\
(\mu \mathrm{m})\end{array}$} & \multirow[t]{2}{*}{ Treatment } & \multicolumn{3}{|c|}{ Porosity (\%) } \\
\hline & & $0-10 \mathrm{~cm}$ & $10-30 \mathrm{~cm}$ & $30-50 \mathrm{~cm}$ \\
\hline \multirow{4}{*}{$\begin{array}{c}\text { FDP } \\
(>50 \mu \mathrm{m})\end{array}$} & T1 & $14.1( \pm 0.97)$ ab & $9.3( \pm 0.90)$ a & $7.8( \pm 1.01)$ ab \\
\hline & $\mathrm{T} 2$ & $16.1( \pm 0.79)$ ab & $14.9( \pm 1.36)$ & $10.1( \pm 0.36)$ a \\
\hline & T3 & $18.0( \pm 2.67)$ a & $9.5( \pm 1.68)$ a & $7.5( \pm 0.74) \quad b$ \\
\hline & T4 & $12.8( \pm 0.63) \quad b$ & $11.7( \pm 0.36) \mathrm{ab}$ & $8.5( \pm 1.23)$ ab \\
\hline \multirow{4}{*}{$\begin{array}{c}\text { SDP } \\
(50-10 \mu \mathrm{m})\end{array}$} & T1 & $5.1( \pm 0.54)$ a & $2.4( \pm 0.48)$ a & $3.1( \pm 0.37)$ a \\
\hline & $\mathrm{T} 2$ & $5.3( \pm 0.38)$ a & $4.3( \pm 0.33) \mathrm{b}$ & $3.1( \pm 0.71)$ a \\
\hline & T3 & $3.5( \pm 0.18) \quad b$ & $2.7( \pm 0.34)$ a & $2.2( \pm 0.19)$ a \\
\hline & T4 & $4.3( \pm 0.29) \quad$ ab & $3.2( \pm 0.33)$ a & $3.4( \pm 0.40)$ a \\
\hline \multirow{4}{*}{$\begin{array}{c}\text { AW } \\
(10-0.2 \mu \mathrm{m})\end{array}$} & T1 & $14.5( \pm 0.80)$ a & $11.0( \pm 1.28)$ a & $13.5( \pm 0.77)$ a \\
\hline & $\mathrm{T} 2$ & $14.2( \pm 0.64)$ a & $14.0( \pm 0.67)$ & $15.3( \pm 0.42) \mathrm{ab}$ \\
\hline & T3 & $23.1( \pm 2.17) \quad b$ & $18.6( \pm 0.84)$ & $16.8( \pm 1.06)$ \\
\hline & T4 & $18.3( \pm 2.69) \mathrm{ab}$ & $14.3( \pm 0.36) \mathrm{b}$ & $13.2( \pm 0.74)$ a \\
\hline
\end{tabular}

Different letters imply significant differences between treatments at the same depth and for the same pore size ( $p<0.05)$. FDP: Fast drainage pores; SDP: Slow drainage pores; AW: Available water. An explanation of the treatments is given in Table 1.

The capacity of soil to transport and store water depends on the proportion and functionality of its pores, thus an adequate proportion of all sizes is important for water flow across the profile. For example, a minimum of $12 \%$ of coarse pores $(>50$ $\mu \mathrm{m})$ is a common reference value for adequate crop development (INIA-ODEPA, 2000). The surface (0$10 \mathrm{~cm}$ ) of all treatments showed FDP $>12 \%$, which as classified by Pagliai and Vignozzi (2002) is in the range of very porous soils. However, the percentage of coarse pores declined sharply in the second horizon
(10-30 cm) of T1 (control) and T3 (manure); this discontinuity is due to a pre-existing plow pan, where the mechanical labours are not transmitted in depth, while in $\mathrm{T} 3$ there was a superficial increase in coarse pores produced by the amendments of manure, maintaining the conditions of the original soil since it was not incorporated at greater depths.

Crop rotations generated a more uniform distribution of coarse pores in the profile; T2 maintained FDP $>12 \%$ up to $30 \mathrm{~cm}$ depth. 
This may be due to the inclusion of crop rotation species with root systems that reach greater depths (Lui et al., 2011), producing a greater capacity to generate coarse pores when the roots decompose (Trükmann et al., 2006).

The SDP did not show important differences among treatments, except for a larger proportion in T2 at $10-$ $30 \mathrm{~cm}$ depth and a smaller proportion in $\mathrm{T} 3$ at $0-10$ $\mathrm{cm}$. The organic nature of the manure favored greater water retention, generating significant differences in the available water (AW) compared to the other treatments. Rotations generated a greater capacity to retain water (AW) than the control, given the generation of new porosity and the contribution of organic material due to the decomposition of the root system (Seguel et al., 2011).

At high tensions water retention is due mainly to adsorption to solid surfaces, which depends on properties such as soil texture and the surface area of the particles, and is less influenced by the structure (Yoon et al., 2007). Therefor, the non-useful water pores (permanent wilting point) did not show differences among treatments, varying between $15 \%$ and $22 \%$ (data not shown).

\subsection{Functionality of the pore system}

The infiltration rate (IR) was obtained from curves relating accumulated infiltration with time. To evaluate the effects of the different treatments, a Student's $t$ test was used to compare the slopes in the range of stabilized curve of accumulated infiltration, resulting in IR values of $16.7 ; 15.9 ; 45.0$ and $18.2 \mathrm{~cm} \mathrm{~h}^{-1}$ for T1, T2, T3 and T4, respectively. The treatment T3 (manure) had significantly higher IR compared with the other treatments $(p<0.5)$.

As the entire pore system participates in water flow in saturated conditions, the greater abundance of coarse pores in the surface of the treatment with manure (T3) favored a stabilized IR significantly greater than the other treatments, a result in agreement with other study (Seguel et al., 2003). This greater infiltration rate was favored by high stability of the macropores, as discussed below. According to Oliver et al. (2013), the values obtained for IR are considered acceptable for soil physical quality with moderately vigorous vines. This classification indicates that in spite of being a fine textured soil with compaction problems, the wetting and drying cycles have stabilized the structure, allowing good infiltration. However, it must be considered that IR is a highly variable property, hence will present variations during season as the soil dries in summer (Zeng et al., 2013).

By other hand, Figure 1 shows the results of air flow obtained with unaltered soil equilibrated to $-33 \mathrm{kPa}$ in a pressure chamber.

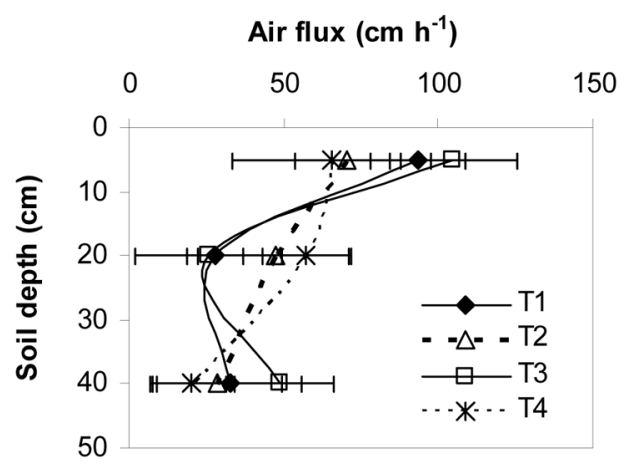

Figure 1. Air flow as a function of soil depth. Each point is the average of five replicates $( \pm \mathrm{SD})$. Significant differences were not detected.

Treatments $\mathrm{T} 1$ and $\mathrm{T} 3 \mathrm{had}$ the greatest air flow at the surface; however, there was a strong decrease at $20 \mathrm{~cm}$ due to the discontinuity generated by the management (Figure 1). Although the mechanical scarification of the control and the application of goat manure in T3 increased the coarse pores and the air flow capacity, they had only a superficial effect and the pore system was discontinuous at $20 \mathrm{~cm}$. 
Treatments $\mathrm{T} 2$ and $\mathrm{T} 4$ showed more continuous air flow in the profile, since the roots of the crop rotations, which included species with different root systems, generated a more stable and functional porosity over time. This effect was also appreciated by Seguel et al. (2011) in a sandy loam soil, in which there was more continuous air flow in the profile using cover crops. In spite of the differences in the graph, given the high variability of this property, these differences were not significant. However, there was a high correlation between the air flow capacity and the fast drainage pores (Figure 2).

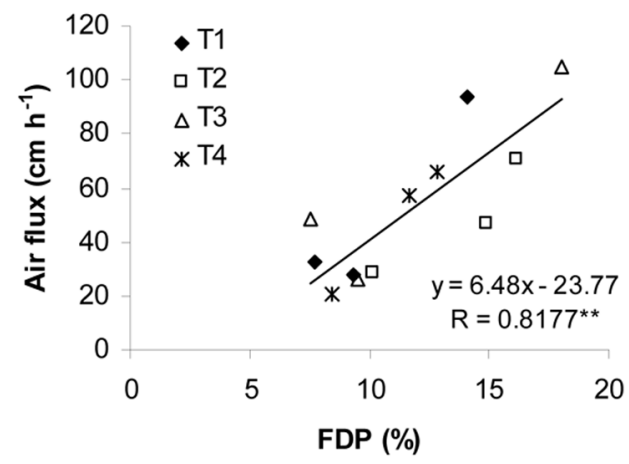

Figure 2. Correlation between fast drainage pores $(\mathrm{FDP},>50 \mu \mathrm{m})$ and air flow $\left(\mathrm{cm} \mathrm{h}^{-1}\right)$.

The samples for water flow were evaluated at a pore water pressure of $-33 \mathrm{kPa}$, which assures that the FDP are empty (full of air); this produced the high correlation, which was significant at $p<0.01(\mathrm{R}=0.82)$. This is an indicator that the pores, which are being generated by the different managements, have sufficient continuity assure the functionality of the soil in the renovation of its air (Pagliai and Vignozzi, 2002).
This functionality was not affected by the possible repellence of water induced by the application of high doses of manure, since all the treatments had $\mathrm{R}$ values in the range of 2 to 4 at the different depths (data not shown). These levels are considered to be sub-critical repellence (Hallett et al., 2001), favoring the slow wetting of the soil, which is desirable to assure good stability of aggregates (Zeng et al., 2013). Hydrophobia is beneficial within these margins, since it promotes stable aggregates of water, which do not form crusts when exposed, thus reducing erosion since the particles do not disperse (Ellies et al., 2005). Values greater than 4 generate an excessive water repellence, which favors superficial runoff on slopes or ridges, or a poor distribution of irrigation water in the soil profile, which did not occur in this study, despite the manure conditioning (Hallet, 2008).

\subsection{Physical-mechanical stability}

Figure 3 shows the results of the rest coefficient (ko), which is the ratio between the horizontal strength and the vertical strength in the same point of the profile.

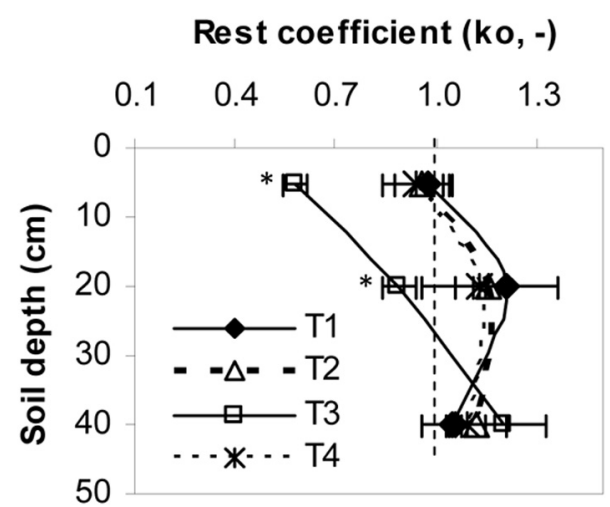

Figure 3. Rest coefficient (ko) as a function of soil depth. The dotted vertical line indicates the threshold for good root growth. The asterisk denotes statistical differences $(p<0.05)$ between manure (T3) and the other treatments. 
Using a criterion of ko $<1$ to consider a soil as not compacted (Hartge and Bachmann, 2004), only at the surface and by a small margin treatments $\mathrm{T} 1$, T2 and T4 showed no compaction; at $20 \mathrm{~cm}$ depth there was increase in ko, indicating a zone of high mechanical resistance, thus representing a problem for the productivity of the soil. High ko values were maintained in depth, although they correspond more to characteristics of the parent material than to a human compaction zone. Even so, treatments with crop rotation (T2 and T4) began to have a remedial effect, although this tendency was lost at greater depths. However, the structural condition observed in the field and the large amount of coarse pores assures a good rooting potential; the mechanical resistance is an inherent condition of the soil given its high clay content.

Treatment T3 showed significant differences from the other treatments down to $30 \mathrm{~cm}$ depth, since the application of manure had a low Db (Table 2) that was much lower than the values found in the other treatments. The manure applications decompressed and aerated the first $30 \mathrm{~cm}$ of soil, but with a constant increase in ko up to $40 \mathrm{~cm}$ depth. The ko values were strongly influenced by the $\mathrm{Db}$; these parameters were highly correlated $(\mathrm{r}=0.84)$, significant at $p<0.01$ (data not shown), result consistent with relation of penetration strength, water content and bulk density described by Stock and Downes (2009).

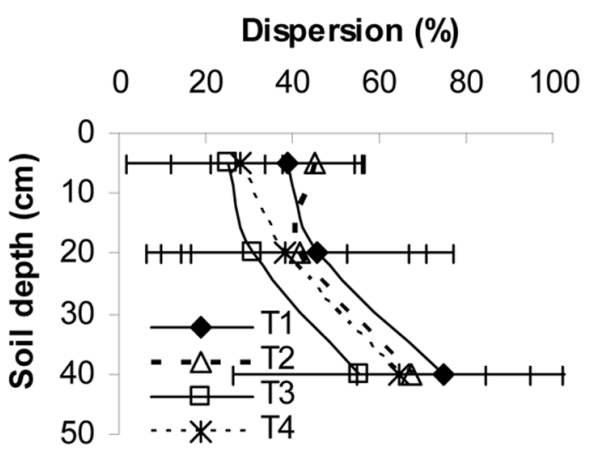

Figure 4. Dispersion of the aggregates (VD 80\%) determined from dry and wet sieving. The differences were not statistically significant.
Water stability is illustrated by Figure 4, which shows the dispersion of soil aggregates sieved in dry and wet condition, considering the diameter at which $80 \%$ of cumulative fraction of the aggregates are intercepted (VD80). Since values are a measure of dispersion, lower values indicate greater stability.

Aggregate stability is one of the most important properties to comprise the physical quality of a soil (Oliver et al., 2013). The greatest stability in the entire profile was found in treatments $\mathrm{T} 3$ and $\mathrm{T} 4$, since both received an important addition of organic material to the soil, either directly as goat manure (T3) or indirectly by crop rotation, mostly grasses (T4). Fasciculate roots predominate in grasses, which increases the possibility of addition of exudates to the entire soil volume, while in $\mathrm{T} 2$ there were mostly tap roots. The lower percentage of dispersion was produced because the organic matter contributes to the stability of the aggregates, since it forms a reticular structure by means of the $-\mathrm{COOH}$-, - $\mathrm{CO}$ - and $\mathrm{OH}$ - groups. This effect is accentuated with the polarity of these unions, favoring a longer-lasting result (Baldock and Nelson, 2000).

Between 10 and $30 \mathrm{~cm}$, the addition of organic material was less and the intensity of the wetting-drying cycles also decreased, thus the treatments showed a similar behavior. It is interesting that $\mathrm{T} 2$ had greater stability at these depths than at the surface, which reflects the importance of crop choice, since T2 (broad bean-cornrape) incorporated a member of the Brassicaceae, which has a deep tap root (Lui et al., 2011) that generates the drying effect sub-superficially.

In depth $(30-50 \mathrm{~cm})$ the four treatments had dispersion values above $50 \%$, showing that the efficacy of the treatments is superficial and that below $30 \mathrm{~cm}$ the natural condition of the soil is maintained, with a weak structure due to low pedological evolution and low biological activity (Horn and Lebert, 1994; Farías, 2009).

The mean weighted diameter (MWD) of the aggregates was significantly different between $\mathrm{T} 3$ and T2 (data not shown). Treatment T2, which had a high 
proportion of coarse pores in the entire profile (Table 3) did not show a high infiltration velocity since it has unstable aggregates (Figure 4), which disperse when they are wetted, sealing the pores and making the soil lose functionality. Thus, rotations that include Brassicaceae are not as effective in improving the physical properties of the soil.

\subsection{Chemical properties of the soil}

As a complement to the physical soil properties, Table 4 shows measurements of parameters related to salinity (composite sample), and Table 5 shows the analysis of fertility.

Table 4. Measurements of electrical conductivity $\left(\mathrm{EC}, \mathrm{dS} \mathrm{m} \mathrm{m}^{-1}\right)$, boron $\left(\mathrm{mg} \mathrm{kg}^{-1}\right)$, chlorine $\left(\mathrm{mg} \mathrm{kg}^{-1}\right)$ and sodium $\left(\mathrm{cmol} \mathrm{kg}^{-1}\right)$ in the soil at two depths $(0-5$ and 20-30 $\mathrm{cm})$ for the four treatments.

\begin{tabular}{|c|c|c|c|c|c|}
\hline \multirow[t]{2}{*}{ Treatment } & \multirow{2}{*}{$\begin{array}{l}\text { Depth } \\
\text { (cm) }\end{array}$} & \multicolumn{4}{|c|}{ Salts } \\
\hline & & $\begin{array}{c}E C \\
\left(\mathrm{dS} \mathrm{m}^{-1}\right)\end{array}$ & $\begin{array}{c}\text { B } \\
\left(\mathrm{mg} \mathrm{kg}^{-1}\right)\end{array}$ & $\begin{array}{c}\mathrm{Cl}^{-} \\
\left(\mathrm{mg} \mathrm{kg}^{-1}\right)\end{array}$ & $\begin{array}{c}\mathrm{Na}^{+} \\
\left(\mathrm{cmol} \mathrm{kg}^{-1}\right)\end{array}$ \\
\hline \multirow[t]{2}{*}{ T1 } & $0-5$ & 11.52 & 1.64 & $\underline{1655}$ & 0.15 \\
\hline & $20-30$ & 0.96 & 0.28 & 23 & 0.71 \\
\hline \multirow[t]{2}{*}{ T2 } & $0-5$ & 4.42 & 1.57 & 261 & $\underline{2.41}$ \\
\hline & $20-30$ & 1.17 & 0.34 & 76 & 0.71 \\
\hline \multirow[t]{2}{*}{ T3 } & $0-5$ & 6.64 & 1.56 & $\underline{920}$ & $\underline{3.93}$ \\
\hline & $20-30$ & 0.95 & 0.32 & 34 & 0.64 \\
\hline \multirow[t]{2}{*}{ T4 } & $0-5$ & 0.89 & 0.28 & 16 & 0.71 \\
\hline & $20-30$ & 2.86 & 1.15 & 55 & $\underline{1.09}$ \\
\hline
\end{tabular}

Values in bold indicate high levels for crop development. An explanation of the treatments is given in Table 1.

The control showed a high salt content at the surface, with levels toxic to crops and an EC considered as strongly saline (Oliver et al., 2013); this occurred because in an exposed soil (without vegetation cover) there is ascending capillary movement from the deeper layers of the profile to the soil surface in which the water evaporates and the salts precipitate, gradually accumulating. In the Copiapó Valley, salinity of irrigation water reaches EC values of $1.07 \mathrm{dS} \mathrm{m}^{-1}$ for superficial water of the Copiapó River and $1.92 \mathrm{dS}$ $\mathrm{m}^{-1}$ for deep well water in the study zone; thus the increase in EC in the first centimeters of soil is due to insufficient washing of the salts.

Comparing the EC values of $\mathrm{T} 1$ to the treatments which included crop rotation (T2 and T4) it is seen that the crop rotation leads to absorption of part of the salts (Baginsky et al., 2010). 
This process is very beneficial in productive zones in which there are problems with the salt content in the soil and the irrigation water, although there appears to be a mechanism of sodium exclusion. The treatment with goat manure (T3) had high EC values, with toxic values of $\mathrm{Cl}^{-}$and $\mathrm{Na}^{+}$(Havlin et al., 1999). The level of this non-stabilized organic material when used as an amendment reaches up to EC levels of $40 \mathrm{dS}$ $\mathrm{m}^{-1}$ (Baginsky et al., 2010) as a consequence of the high concentration of soluble salts, and is thus not recommended for use in this productive area.

Table 5. Characterization of the study site at the end of the evaluation period $(0-20 \mathrm{~cm}$ depth). Means $( \pm$ standard error of the mean).

\begin{tabular}{cccccc}
\hline Treatment & $\mathbf{p H}$ & $\begin{array}{c}\mathbf{O M} \\
\mathbf{( \% )}\end{array}$ & $\begin{array}{c}\text { Nitrogen } \\
\mathbf{( \% )}\end{array}$ & $\begin{array}{c}\text { Phosphorous } \\
\left(\mathbf{m g ~ k g}^{-\mathbf{1}}\right)\end{array}$ & $\begin{array}{c}\text { Potassium } \\
\left(\mathbf{c m o l}+\mathbf{k g}^{-\mathbf{1}} \mathbf{)}\right.\end{array}$ \\
\hline T1 & $8.03( \pm 0.06)$ a & $2.81( \pm 0.19)$ a & $0.15( \pm 0.01)$ a & $42.8( \pm 11.5)$ ab & $2.01( \pm 0.16)$ ab \\
T2 & $8.20( \pm 0.02)$ a & $2.07( \pm 0.06)$ a & $0.10( \pm 0.01)$ a & $12.6( \pm 2.0)$ a & $1.48( \pm 0.11)$ a \\
T3 & $7.96( \pm 0.06)$ a & $6.16( \pm 1.03)$ b & $0.32( \pm 0.05)$ b & $207.0( \pm 71.5)$ b & $2.34( \pm 0.13)$ b \\
T4 & $8.00( \pm 0.11)$ a & $2.62( \pm 0.26)$ a & $0.13( \pm 0.01)$ a & $42.2( \pm 4.6)$ ab & $1.54( \pm 0.15)$ a \\
\hline
\end{tabular}

Different letters in the same column indicate significant differences among treatments $(p<0.05)$. An explanation of the treatments is given in Table 1.

The soil in which the study was performed has a moderately alkaline condition, with $\mathrm{pH}$ values above 7 in all treatments. This condition is favored by the presence of fine texture and calcium carbonates in the entire profile. Alkalinity can be alleviated with applications of organic material that favours a lower $\mathrm{pH}$. This effect was manifested in treatment T3 (manure), although after three years it was not significantly different from the other treatments.

Treatment T3 (manure) showed significantly greater quantities of organic material and macronutrients, especially in nitrogen in which it was greater than the other treatments. Sierra and Rojas (2002) indicated that since this type of amendment is not composted it has high values of organic material and nitrogen; however, they also remarked that this material is more prone to loss by volatilization and can add important amount of salts.
The crop rotation that removed the most nutrients from the soil was that of broad bean, corn and rape (T2) although these values were not significant compared to control. Nutrient levels were in medium to high ranges, which indicates that the soil has a good level of fertilization. Together, this implies that the production results of vines will depend mainly on the physical properties of the soil.

\subsection{Evaluations in the vines}

The evaluations of the grape plants were intended to determine if there was competition between the treatments and the vine plants. Figure 5 shows the production of dry matter of fine $(<2 \mathrm{~mm})$ and coarse $(>2 \mathrm{~mm})$ roots of vines measured at two depths $(0-20$ $\mathrm{cm}$ and 20-40 cm) in October, 2009. 

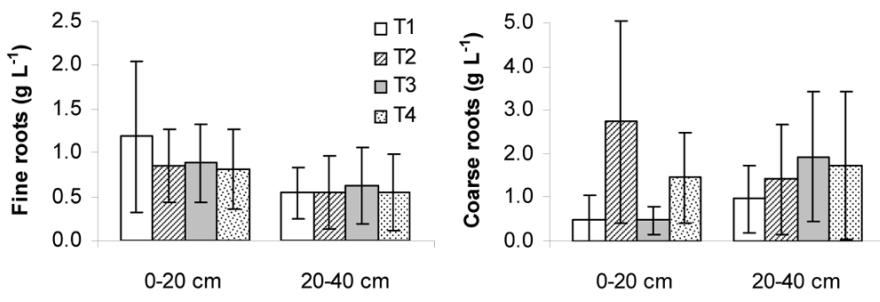

Figure 5. Dry matter of fine roots (left) and coarse roots (right). The differences among treatments were not significant.

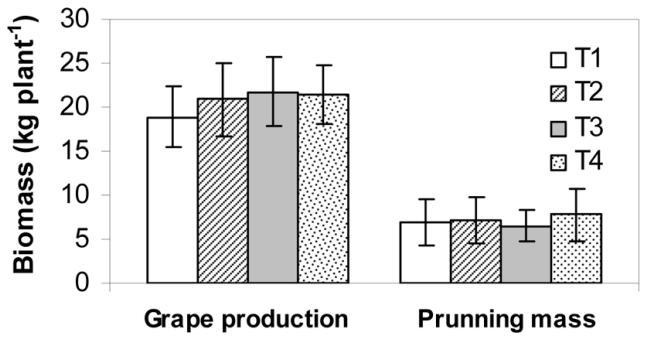

Figure 6. Commercial grape production and pruning mass for the different treatments after three years. No significant differences were found among treatments for either variable.

In the control (T1) it may be supposed that soil temperature influenced the development of fine roots, since being bare it maintained higher temperatures, probably close to the optimum for physiological development. However, the amount of root growth was not significantly different from the other treatments, and the differences were less at greater depth. Although the application of organic amendments favors the development of roots by improving the physical conditions of the soil (Kay, 1990), in this case treatment $\mathrm{T} 3 \mathrm{did}$ not stand out, possibly due to an adverse effect of the salinity provided by the manure. Although the high variability among replicates in the amount of coarse roots did not allow the differences to be significant; T4 had a more uniform distribution in the soil profile.

Finally, Figure 6 shows the yields and pruning mass after the three years of the trial.

The treatments did not produce a greater commercial production of table grapes compared to the control, but if the tendency is projected over a longer time period, there may be a significant increase in production. There was high plant vigor in all treatments. Treatments which included crop rotations (T2 and T4) had greater pruning weights than the control (T1), which indicates that cultivation with cover crops resulted in better physical characteristics of the soil and led to a better response in the grape. Importantly, the treatments which included crop rotations did not present competition or limitation for the normal development of the vines, since their phenological development coincided with the period of recess of the grape plants. The soil system was positively affected by the presence of cover crops in the ridges. However, there was a complex interaction among the physical, chemical and biological subsystems which requires more implementation time of these practices to achieve positive effects in grape culture. 


\section{Conclusions}

Successive applications of organic material on the ridges of grape plantations row of a table grape vine orchard had positive effects on the physical properties of the soil in comparison with crop rotation treatments. Applications of goat manure decrease the penetration strength and bulk density, as well as it increased the retention and flow of water in the top soil only. Cover crops were effective in generating porosity in the entire profile due to the root growth of crops, promoting a better continuity of the pore network system which helps promote greater permeability of air. The use of goat manure was effective in reducing the degree of soil compaction, since the direct application of organic material generates an important reduction in soil strength. Cover crops produced a non-significant decrease on compaction, while corn-broad bean-rye rotation increase the aggregate stability as did manure addition. We assume that the amendment management was too short to notice an improvement in the soil physical properties to better reflected an increase in the yields of grapes.

\section{Acknowledgements}

The authors thank Aldo Ghiglino and their family for their support during field work. This study was financed by project INNOVA-Chile of CORFO (05 CR11IAT-06). We acknowledge to the Associate Editor Dr. F. Matus for their helpful comments on early version of the paper.

\section{References}

Baginsky, C., Seguel, O., Contreras, A. 2010. Impacto en la utilización de cultivos y enmiendas orgánicas sobre la funcionalidad del suelo. Facultad de Ciencias Agronómicas, Serie Ciencias Agronómicas $\mathrm{N}^{\mathrm{o}}$ 17. Universidad de Chile. Santiago, $143 \mathrm{p}$.
Baldock J., Nelson, P. 2000. Soil organic matter. In: M. Sumner (ed.) Handbook of Soil Science. CRC Press. Washington, D.C., pp: B25-B71.

Chenu, C., Plante, A.F. 2006. Clay-sized organomineral complexes in a cultivation chronosequence : revisiting the concept of the 'primary organomineral complex'. European Journal of Soil Science. 57, 596-607.

CIREN. 2007. Estudio Agrológico del Valle del Copiapó y Valle del Huasco. Descripciones de suelos, materiales y símbolos. Publicación № 135 . $126 \mathrm{p}$.

Dane, J., Hopmans, J. 2002. Water retention and storage. In: J. H. Dane, G.C. Topp (eds.) Methods of soil analysis. Parth 4. Physical methods. SSSA. Madison, Wisconsin. USA, pp: 671-720.

Dörner, J., Horn, R. 2006. Anisotropy of pore functions in structured Stagnic Luvisols in the Weichselien moraine region in North Germany. J. Plant Nutr. Soil Sci. 169, 213- 220.

Ellies, A. 1995. Efecto del manejo sobre las propiedades físicas de suelos trumaos y rojo arcillosos. Bosque. 16, 101-110.

Ellies, A., Ramírez, C., Mac Donald, R. 2005. Organic matter and wetting capacity distribution in aggregates of Chilean soils. Catena. 59, 69-78.

Farías, E. 2009. Cambio en las propiedades físicas de un suelo en laderas cultivadas con vid (Vitis vinifera). Memoria de Título. Universidad de Chile, Facultad de Ciencias Agronómicas, Santiago, Chile, 40p.

Flint, A.L., Flint L.E. 2002. The solid phase. Particle density. In: J. Dane, G.C. Topp. (eds.) Methods of soil analysis. Part 4. Physical methods. SSSA. Madison, Wisconsin, USA, pp: 229-240. 
Gee, G.W., Or, D. 2002. Particle size analysis. In: J. Dane, G.C. Topp. (eds.) Methods of soil analysis. Part 4. Physical methods. SSSA. Madison, Wisconsin, USA, pp: 255-293.

Grossman, R., Reinsch, T. 2002. Bulk density and linear extensibility. In: J. Dane, G.C. Topp. (eds.) Methods of soil analysis. Part 4. Physical methods. SSSA. Madison, Wisconsin, USA, pp: 201-228.

Hallet, P. 2008. A brief overview of the causes, impacts and amelioration of soil water repellency. A review. Soil \& Water Res. 3 (Special Issue 1), S21-S29.

Hallett, P., Baumgartl, T., Young, I. 2001. Subcritical water repellency of aggregates from a range of soil management practices. J. Soil Sci. 65,184-190.

Hartge, K., Bachmann, J. 2004. Ermitlung des Spannungszustandes von Böden aus Werten des Eindringwiderstandes von Sonden. J. Plant Nutr. Soil Sci. 167, 304-308.

Hartge, K., Horn, R. 2009. Die physikalische Untersuchung von Böden. E. Schweizerbart'sche Verlagsbuchhandlung. Stuttgart, Germany, 178 p.

Havlin, J., Beaton, J., Tisdale, S., Nelson, W. 1999. Soil Fertility and Fertilizers. An introduction to nutrient management. Sixth Edition. Prentice Hall. Upper Saddle River, New Jersey. USA, 499 p.

Horn, R., Lebert, M. 1994. Soil compactability and compressibility. In: B. D. Soane, C. van Ouwerkerk (eds.). Soil compaction in crop production. Elsevier Science. Amsterdam, The Netherlands, pp: 45-69.

INIA-ODEPA (Chile). 2000. Proyecto sistemas de validación y transferencia de tecnologías de riego sector regado de las provincias de San Felipe y Los Andes. Convenio INIA-ODEPA. Instituto de Investigaciones Agropecuarias, Centro Regional de Investigación La Platina. Oficina de Estudios y Políticas Agrarias. Santiago. Chile. 52 p.
Juliá, C., Montecinos, S., Maldonado, A. 2008. Características climáticas de la Región de Atacama. In: F.A. Squeo, G. Arancio, J.R. Gutiérrez (eds). Libro Rojo de la Flora Nativa y de los Sitios Prioritarios para su Conservación: Región de Atacama. Ediciones Universitarias de La Serena. La Serena, Chile. pp: 25-42.

Kay, B. 1990. Rates of change of soil structure under different cropping systems. Adv. Soil Sci. $12,1-4$.

Leeds-Harrison, P., Young, E. Uddin, B. 1994. A device for determining the sorptivity of soil aggregates. Eur. J. Soil Sci. 45, 269-272.

Lui, L., Gan, Y., Bueckert, R., Van Rees, A. 2011. Rooting systems of oilseed and pulse crops. II: Vertical distribution patterns across the soil profile. Field Crops Res. 122 (3), 248-255.

Montico, S., Bonel, B. 2005. Influencia de la compactación por tránsito sobre la arquitectura de las raíces. In: D. Jorajuría (ed). Reología del suelo agrícola bajo tráfico. Universidad Nacional de la Plata. Argentina, pp: 13-20.

Oades, J.M. 1993. The role of the biology in the formation, stabilization and degradation of soil structure. Geoderma. 56, 377- 400.

Oliver, D.P., Bramley, R.G.V., Riches, D., Porter, I., Edwards, J. 2013. Review: soil physical and chemical properties as indicators of soil quality in Australian viticulture. Australian Journal of Grape and Wine Research 19(2), 129-139.

Pagliai, M., Vignozzi, N. 2002. The soil pore system as an indicator of soil quality. In: M. Pagliai, R. Jones (eds). Sustainable land management-environmental protection. A soil physical approach. Advances in Geoecology. 35. IUSS. Catena Verlag. Reiskirchen. Germany, pp: 71-82. 
Poblete, L. 2011. Modificación de las propiedades físicas de un suelo de textura fina de la III Región cultivado con vid, mediante la incorporación de materia orgánica en la sobre hilera. Memoria Ing. Agrónoma. Universidad de Chile, Facultad de Ciencias Agronómicas. 47 p.

Reynold, W., Elrick, D., Youngs, E., Amoozegar, A., Booltink, H.W., Bouma, J. 2002. Saturated and field saturated water flow parameters. In: J.H. Dane, G.C. Topp (eds). Methods of soil analysis. Parth 4. Physical methods. SSSA. Madison, Wisconsin, USA, pp: 797-878.

Sadzawka, A., Carrasco, M.A., Grez, R., Mora, M. L. 2004. Métodos de análisis recomendados para los suelos chilenos. Comisión de Normalización y Acreditación. Sociedad Chilena de la Ciencia del Suelo. Santiago, Chile, 113 p.

Seguel, O., Baginsky, C., Contreras, A., Covarrubias, J., González, C., Sandoval, M. 2011. Changes in physical properties of a Typic Haplocambid by annual crop culture. J. Soil Sci. Plant Nutr. 11(1), 1-15.

Seguel, O., García de Cortázar, V., Casanova, M. 2003. Variación en el tiempo de las propiedades físicas de un suelo con adición de enmiendas orgánicas. Agric. Téc. 63(3), 287-297.

Sierra, B., Rojas, C. 2002. La materia orgánica y su efecto como enmienda y mejorador de la productividad de los cultivos. Informe Técnico Estación Experimental Intihuasi, Instituto de Investigaciones Agropecuarias INIA, La Serena, Chile, $20 \mathrm{p}$.
Stock, O., Downes, N.K. 2009. Effects of additions of organic matter on the penetration resistance of glacial till for the entire water tension range. Soil Till. Res. 99, 191-201.

Terzaghi, K., Peck, R. H. 1983. Mecánica de suelos en la ingeniería práctica. Ed. El Ateneo, Buenos Aires, Argentina, 681 p.

Trükmann, K., Reintam, E., Kuht, J., Rääts, V. 2006. Growing of Mugwort (Artemisia vulgaris L.), Canadian Thistle (Cirsium arvense L.) and Yellow Lupine (Lupinus luteus L.) on compacted soil. In: R. Horn, H. Fleige, S. Peth, X. Peng (eds). Soil management for Sustainability. Advances in Geoecology. 38. IUSS. Catena Verlag. Reiskirchen. Germany, pp: 362-369.

Warrick, A.W. (Ed.). 2002. Soil Physics Companion. CRC Press. Boca Raton, USA, 389 p.

Yoon, Y., Kim, J., Hyun, S. 2007. Estimating soil water retention in a selected range of soil pores using tension disc infiltrometer data. Soil Till. Res. 97, 107-116.

Zeng, C., Wang, Q., Zhang, F., Zhang, J. 2013. Temporal changes in soil hydraulic conductivity with different soil types and irrigation methods. Geoderma. 193-194, 290-299.

Zhang, H., Hartge, K., Ringe, H. 1997. Effectiveness of organic matter incorporation in reducing soil compactibility. Soil Sci. Soc. Am. J. 61, 239-245. 